\title{
The Role of S100A8 and S100A9 in Differentiation of Human Eosinophilic Leukemia Cells, EoL-1
}

\author{
In Sik Kim ${ }^{1,2, \dagger}$, Ayoung $\mathrm{Gu}^{1}$ and Ji-Sook Lee ${ }^{3, \dagger}$ \\ ${ }^{I}$ Department of Senior Healthcare, BK21 plus program, Graduate School, Eulji University, Daejeon 34824, Korea \\ ${ }^{2}$ Department of Biomedical Laboratory Science, School of Medicine, Eulji University, Daejeon 34824, Korea \\ ${ }^{3}$ Department of Clinical Laboratory Science, Wonkwang Health Science University, Iksan 54538, Korea
}

S100A8 and S100A9 are associated with myeloid cell differentiation, chemotactic activities, adhesion of neutrophils, and apoptosis. In this study, we investigated the contribution of S100A8 and S100A9 to differentiation of the human eosinophilic leukemia cell line, EoL-1. S100A8 and S100A9 increased the number of vacuole per one cell and the protein expression of EPO and MBP. Rottlerin, an inhibitor of protein kinase C delta (PKC $\delta$ ), inhibited the EoL-1 cell differentiation induced by S100A8 and S100A9. These results suggest that S100A8 and S100A9 may regulate the differentiation of eosinophilic progenitors. Moreover, these findings may shed light on elucidation of eosinophil differentiation due to S100 proteins.

Key Words: S100, Differentiation, Eosinophil, PKC $\delta$

S100A8 and S100A9, which belong to the S100 family of proteins, constitutively expressed in neutrophils and monocytes (Goyette and Geczy, 2011; Kerkhoff et al., 2012; Nam et al., 2016). These proteins act as damage-associated molecular pattern (DAMP) via receptor for advanced glycation endproducts (RAGE) or Toll-like receptor 4 (TLR4). Idiopathic hypereosinophilic syndrome (HES) is a rare myeloproliferative disease that is distinguished from chronic eosinophilic leukemia (CEL) by the identification of clonality or by increased numbers of eosinophilic blasts (Gotlib et al., 2004; Tefferi et al., 2006). EoL-1 cells can be used as an in vitro model for research of this disease. Expression of S100A8 and S100A9 is related to with acute myeloid leukemia (AML) and acute lymphoblastic leukemia (ALL)
(Spijkers-Hagelstein et al., 2012; Nicolas et al., 2011). However, the effects of S100A8 and S100A9 on the differentiation of eosinophils are currently unknown; therefore, this study investigated the effects of S100A8 and S100A9 on differentiation of human eosinophilic leukemia cells, EoL-1.

EoL-1 cells were incubated in the absence or presence of butyric acid, S100A8 or S100A9 during 12 days, and were placed on a slide using a cytospin. The cells were air-dried and then stained with Wright stain. Finally, the cells were mounted with mounting solution and morphological changes in the cells were examined under light microscopy. EoL-1 cells seeded into 6 well plates at $5 \times 10^{5}$ cells/well were cultured in RPMI 1640. After treatment with butyric acid for 12 days, the cells were harvested and washed with PBS

\footnotetext{
* Received: March 12, 2017 / Accepted: April 3, 2017
}

${ }^{\dagger}$ Corresponding author: Ji-Sook Lee. Department of Clinical Laboratory Science, Wonkwang Health Science University, Iksan 54538, Korea. Tel: +82-63-840-1216, Fax:+82-63-840-1219, e-mail: jslee1216@wu.ac.kr

${ }^{\dagger}$ Corresponding author: In Sik Kim. Department of Biomedical Laboratory Science, School of Medicine, Eulji University, Daejeon 34824, Korea. Tel: +82-42-259-1753, Fax: +82-42-259-1759, e-mail: orientree@eulji.ac.kr

(C) The Korean Society for Biomedical Laboratory Sciences. All rights reserved.

(c) This is an Open Access article distributed under the terms of the Creative Commons Attribution Non-Commercial License (http://creativecommons.org/licenses/by-nc/3.0/) which permits unrestricted non-commercial use, distribution, and reproduction in any medium, provided the original work is properly cited. 
A

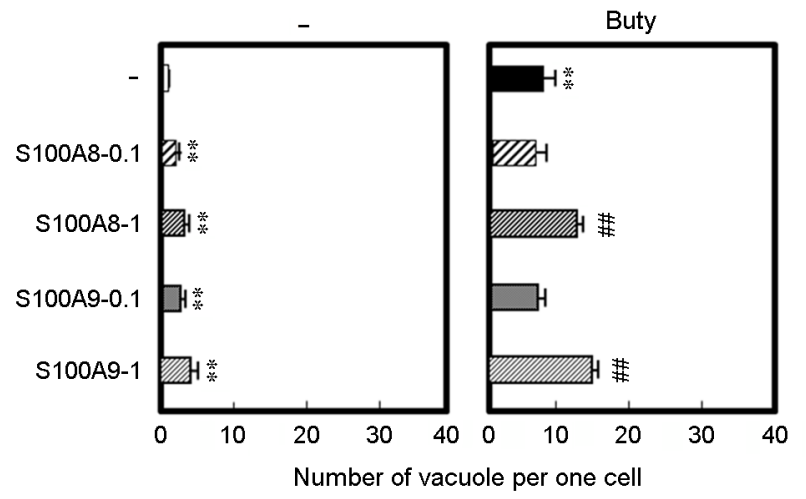

B

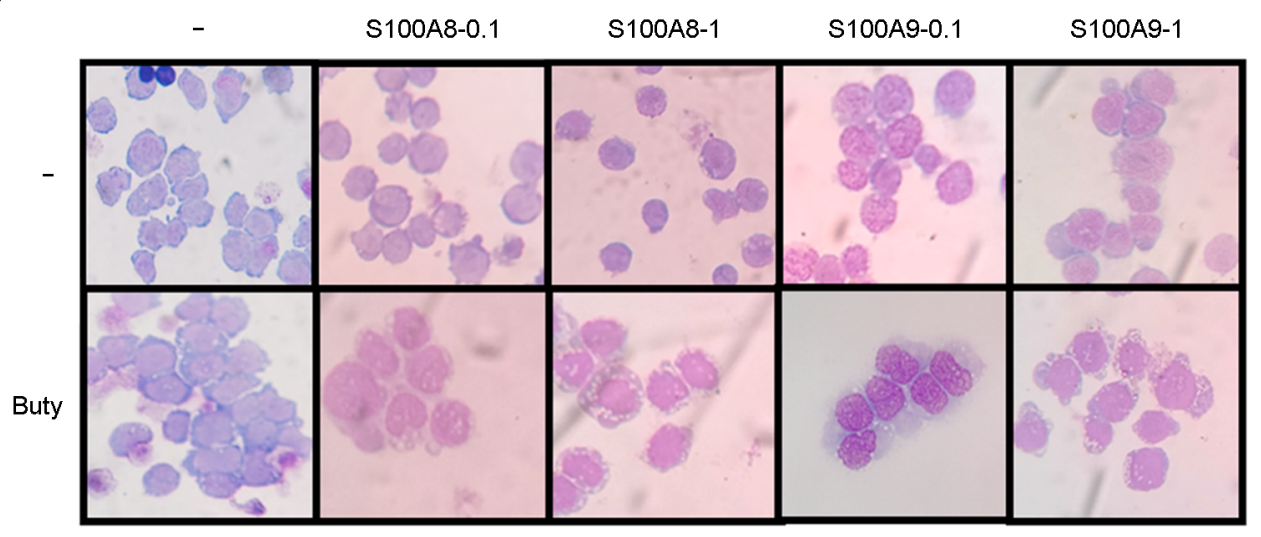

C
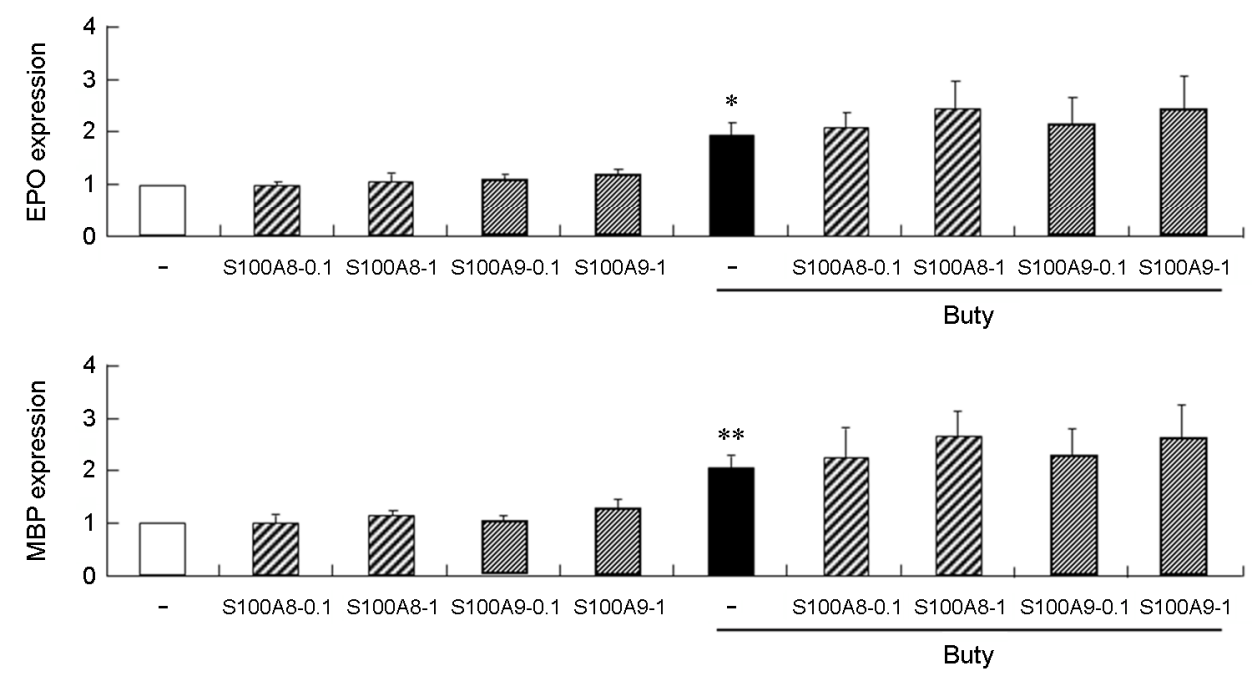

Fig. 1. S100A8 and S100A9 induce the differentiation of EoL-1 cells. (A) EoL-1 cells were treated without and with $0.1 \mu \mathrm{g} / \mathrm{mL}$ and $1 \mu \mathrm{g} /$ $\mathrm{mL}$ of S100A8 and S100A9, and $0.5 \mathrm{mM}$ butyric acid (Buty) for 12 days. The cells were centrifuged using cytospin and stained with Wright stain for observation of morphological change. The number of vacuoles per one cell was determined by counting at least 100 cells. (B) Photograph of differentiated cells $(\times 400)$. (C) EoL-1 cells were treated without and with $0.1 \mu \mathrm{g} / \mathrm{mL}$ and $1 \mu \mathrm{g} / \mathrm{mL}$ of S100A8 and S100A9, and $0.5 \mathrm{mM}$ butyric acid (Buty) for 12 days. The cells were harvested and analyzed using a fluorescence activated cell sorter with anti-EPO or anti-MBP antibodies. Baseline fluorescence values were obtained by incubation with normal mouse IgG. Data are expressed as the means \pm SD. $* P<0.05$ and $* * P<0.01$ indicate a significant difference between the control and the S100A8, S100A9, or butyric acid-treated group. $\# P<0.05$ and $\# P<0.01$ indicate a significant difference between the butyric acid-treated group and the butyric acid/S100A8 or butyric acid/S100A9-treated group. 

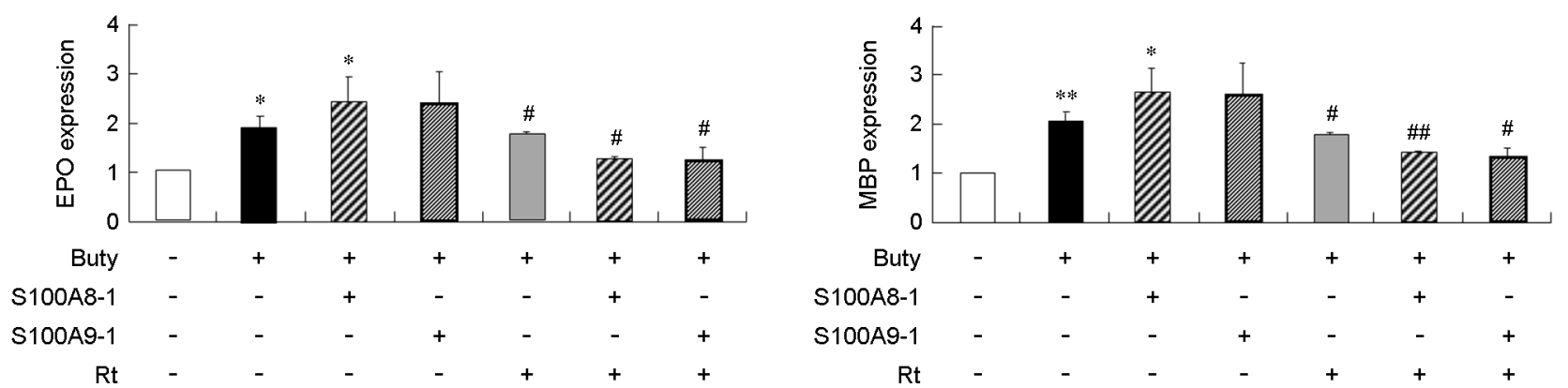

Fig. 2. PKC $\delta$ is associated with the differentiation induced by S100A8 and S100A9. EoL-1 cells were incubated without and with $1 \mu \mathrm{M}$ rottlerin (Rt), $1 \mu \mathrm{g} / \mathrm{mL} \mathrm{S100A8}$ and S100A9, and $0.5 \mathrm{mM}$ butyric acid (Buty) at $37^{\circ} \mathrm{C}$ for 12 days. The cells were harvested and analyzed using a fluorescence activated cell sorter with anti-EPO or anti-MBP antibodies. Baseline fluorescence values were obtained by incubation with normal mouse IgG. Data are expressed as the mean \pm SD. ${ }^{*} P<0.05$ and $* * P<0.01$ indicate a significant difference between the control and the butyric acid-treated group or between the butyric acid-treated group and the butyric acid/S100A8 or butyric acid/S100A9 group. $\# P<0.05$ and $\# P<0.01$ indicate a significant difference between the butyric acid-treated group and the butyric acid/rottlerin group or between the butyric acid/S100A8 and butyric acid/S100A8/rottlerin or between the butyric acid/S100A9 and butyric acid/S100A9/rottlerin.

buffer containing $0.5 \%$ BSA. Non-specific antibody binding was blocked by incubating the cells with normal rabbit IgG. The cells were separated into new tubes and PBS buffer containing anti-EPO or anti-MBP antibodies was added to each tube. After washing 3 times, the cells were incubated at $4{ }^{\circ} \mathrm{C}$ for $30 \mathrm{~min}$ with FITC-conjugated goat anti-mouse IgG. Finally, the cells were washed and analyzed using a Guava easyCyte Flow Cytometers (Merck Millipore, Darmstadt, Germany). Here, we investigated whether S100A8 and S100A9 affect alterations in eosinophil differentiation for the first time. S100A8 and S100A9 increased the number of vacuoles (Fig. 1A and B) and expression of EPO and MBP in EoL-1 cells during butyric acid-induced differentiation with or without statistical significance (Fig. 1C). As shown in Fig. 2, PKC $\delta$ activation was related to the differentiation induced by S100A8 and S100A9 because the differentiation was suppressed by rottlerin. In a previous study, Lkn-1 induced EoL-1 cell differentiation through PKC $\delta$ activation (Lee and Kim, 2010). PKC isoforms are important intracellular signaling molecules in cell differentiation, migration, proliferation and activation (Steinberg, 2008). Also, the overexpression of $\mathrm{PKC} \delta$ is associated with inhibition of proliferation and enhancement of differentiation in various cell lines (Wang et al., 2014; Chen et al., 2015). These findings suggest that S100A8 and S100A9 induce the differentiation of immature eosinophils through $\mathrm{PKC} \delta$ activa- tion. It is still not known how S100A8 and S100A9 exert downstream signal after $\mathrm{PKC} \delta$ activation. Major clinical features such as organ enlargement in patients with CEL is caused by increased CEL cells (Gotlib et al., 2004). We think that S100A8 and S100A9 play as essential factors in normal eosinophil differentiation, and both proteins may be useful as therapeutic drugs for the treatment of CEL by pro moting the differentiation of immature CEL cells. Further study is required to elucidate the exact relationship of differentiation induced by S100A8 and S100A9 and pathogenesis of CEL.

\section{Acknowledgements}

This research was supported by the Basic Science Research Program through the National Research Foundation of Korea (NRF) funded by the Ministry of Science, ICT \& Future Planning (2015R1C1A2A01055106).

\section{Conflict of interest}

We have no conflict of interest to declare.

\section{REFERENCES}

Chen B, Miller AL, Rebelatto M, Brewah Y, Rowe DC, Clarke L, Czapiga M, Rosenthal K, Imamichi T, Chen Y, Chang CS, Chowdhury PS, Naiman B, Wang Y, Yang D, Humbles AA, 
Herbst R, Sims GP. S100A9 induced inflammatory responses are mediated by distinct damage associated molecular patterns (DAMP) receptors in vitro and in vivo. PLoS One. 2015. 10: e0115828.

Gotlib J, Cools J, Malone JM 3rd, Schrier SL, Gilliland DG, Coutré SE. The FIP1L1-PDGFR alpha fusion tyrosine kinase in hypereosinophilic syndrome and chronic eosinophilic leukemia: implications for diagnosis, classification, and management. Blood. 2004. 103: 2879-2891.

Goyette J, Geczy CL. Inflammation-associated S100 proteins: new mechanisms that regulate function. Amino Acids. 2011. 41: 821-842.

Kerkhoff $\mathrm{Cl}$, Voss A, Scholzen TE, Averill MM, Zänker KS, Bornfeldt KE. Novel insights into the role of S100A8/A9 in skin biology. Experimental Dermatology. 2012. 21: 822-826.

Lee JS, Kim IS. Leukotactin-1/CCL15 induces cell migration and differentiation of human eosinophilic leukemia EoL-1 cells through PKC delta activation. Molecular Biology Reports. 2010. 37: 2149-2156.

Nam AR, Kim DH, Kim MJ, Lee JS, Yang SJ, Kim IS. S100A8 induces secretion of MCP-1, IL-6, and IL-8 via TLR4 in Jurkat T cells. Biomedical Science Letters. 2016. 22: 60-64.

Nicolas E, Ramus C, Berthier S, Arlotto M, Bouamrani A, Lefebvre C, Morel F, Garin J, Ifrah N, Berger F, Cahn JY, Mossuz P. Expression of S100A8 in leukemic cells predicts poor survival in de novo AML patients. Leukemia. 2011. 25: 57-65.

Spijkers-Hagelstein JA, Schneider P, Hulleman E, de Boer J, Williams O, Pieters R, Stam RW. Elevated S100A8/S100A9 expression causes glucocorticoid resistance in MLL-rearranged infant acute lymphoblastic leukemia. Leukemia. 2012. 26: 1255 -1265 .

Steinberg SF. Structural basis of protein kinase $\mathrm{C}$ isoform function. Physiological Reviews. 2008. 88: 1341-1378.

Tefferi A, Patnaik MM, Pardanani A. Eosinophilia: secondary, clonal and idiopathic. British Journal of Haematology. 2006. 133: 468-492.

Wang L, Luo H, Chen X, Jiang Y, Huang Q. Functional characterization of S100A8 and S100A9 in altering monolayer permeability of human umbilical endothelial cells. PLoS One. 2014. 9: e90472. 